\title{
ANDRÉE LAJOIE, LA VIE INTELLECTUELLE DE RODERICK MACDONALD: UN ENGAGEMENT (Montréal: Les Éditions Thémis, 2014)
}

\section{Christopher Waters*}

For roughly three and a half decades before his passing on June 13, 2014, Roderick Macdonald was a maverick on the Canadian legal education scene. As a law teacher, scholar, dean and reformer, Macdonald inspired generations of jurists, including this reviewer. La vie intellectuelle de Roderick Macdonald is a short biographical sketch of Macdonald written by Andrée Lajoie, Professor Emeritus at the Université de Montréal and sometime collaborator with her subject. I think it is fair to surmise that Lajoie wrote the book in some haste. The book has typographical errors and it sometimes seems written as a near-final draft. However, given the state of Macdonald's health -he was in advanced stages of throat cancer at the time of publication- and the desire to honour Macdonald in a timely way (the book was launched at a symposium in Macdonald's honour held at McGill University in 2014) ${ }^{1}$ this is entirely forgivable. Furthermore, any stylistic flaws are more than compensated by the compelling sketch of Macdonald's career, scholarship and ideas.

Chapter One provides the biographical bones to the rest of the book. It details Macdonald's youth (a middle child with inconsistent grades, raised in a "WASPish" environment near Toronto), his growing commitment to social justice during the Vietnam era, his studies (a B.A. at York, an LL.B. at Osgoode Hall, an LL.L. at Ottawa for a dose of Civil Law, and an LL.M. at Toronto under the tutelage of John, now Angela, Swan). It also touchingly describes his marriage to Shelley Freeman, an artist on whom he drew for inspiration throughout his adult life.

Chapter Two is entitled "Avant tout professeur" and portrays Macdonald's primary commitment to law teaching and mentorship. For Macdonald, teaching was not something to "get in the way" of scholarship or service to a wider legal and non-legal public; rather, law teaching was a vocation and, to use his words, "a way of being alive". ${ }^{2}$ At the same time, Lajoie suggests, Macdonald was a professor above being a jurist; his commitment to law teaching was anti-instrumentalist and he could as easily have been a professor in a cognate discipline. Rather than trying to train lawyers, Macdonald consistently trained law students to think, to challenge dogma, and to seek social justice and virtue. Perhaps particularly of interest to readers of this journal, Chapter Two details Macdonald's hiring at the University of Windsor when, after a string of rejections, this was the first university to offer him an interview:

"[I]l remarque le Community Law Program, une clinique juridique et un programme en information juridique pour le grand public. Séduit par ces orientations, il sait immédiatement que c’est dans cette université qu'il veut enseigner, sans même se rendre dans les deux autres."

* Professor, Faculty of Law, University of Windsor. Rod Macdonald was his doctoral supervisor at McGill.

1 The Symposium recordings are available online; see "Unbounded Level of the Mind: Rod Macdonald's Legal Imagination” (Montreal, 7-8 February 2014), online: McGill <https://www.mcgill.ca/macdonald-symposium/>.

$2 \quad$ La Vie Intellectuelle de Roderick Macdonald at 23.

$3 \quad$ La Vie Intellectuelle de Roderick Macdonald at 14. 
Among other accomplishments at Windsor, Macdonald and his colleagues transformed a Winnebago into a library and in the summers toured northern Ontario providing legal information to the public. ${ }^{4}$ This commitment to public engagement with law was to continue throughout his career, including in his capacity as President of the Law Commission of Canada.

As Lajoie portrays in Chapter Three, if Macdonald's commitment to law teaching was unwavering, so was his commitment to scholarship. This chapter is a review essay of Macdonald's scholarship, detailing six key areas in which he has made a lasting mark. These areas are legal theory, access to justice, civil law, securities, constitutional law and administrative law. Many observers would agree that Macdonald's most original contribution has been in the first category, legal theory. His understanding of legal pluralism has been front and centre in that category. Macdonald has taken a legal pluralist approach to, among other areas, national identity, law and language, aboriginal law and "law in everyday life". In recent years, his pioneering of the field of critical legal studies has garnered particular attention. Moving beyond the essentialist versions of ordinary legal pluralism (where the state remains at the centre of things even while other normative orders are classified and probed), Macdonald pursued a non-essentialist, non-hierarchical version of legal pluralism where the subjects of law are not only law abiding but "law inventing" as well. ${ }^{5}$ In other words, law is a two-way street between institutional lawgiver and citizen but also a shifting and dynamic creation of relations between citizens. It is worth noting here that a 26-page appendix to the book contains a full list of Macdonald's publications.

Chapter Four provides an account of Macdonald bringing his ideas into an institutional setting, whether as a social activist, as a transformational dean of McGill's Law Faculty from 1984-1989 (where, among other things he introduced the National Law Program and helped reconcile the Faculty to its existence in modern Quebec) and as a law commissioner. In the latter role he led three commissions (the Quebec Commission on Access to Justice, the Law Commission of Canada and an advisory committee on SLAPPs or "strategic litigation against public participation” for the Quebec government). More recently, he was a member of the Charbonneau Commission looking into corruption in Quebec's construction industry, although his health forced him to work behind the scenes on this one. He was a researcher for six other commissions. Many of his recommendations as a commissioner have been implemented by governments, including recommendations on gay marriage and residential schools made during his leadership of the Law Commission of Canada.

In addition to relying on documentary sources, the book draws on interviews with Macdonald and others who have known Macdonald at various phases of his life (including Windsor Law Professor Emeritus George Stewart). In the final chapter, one of the interviewees, Richard Janda, a colleague of Macdonald's at McGill, is asked to sum up Macdonald's impact. According to Janda, “des facultés de droit de tous les continents enseignent des éléments de ce que l’on peut qualifier de curriculum de

4 More on the Community Law Program and its "Community Law Caravan” can be found in Annette Demers, A History of the University of Windsor, Faculty of Law 1968-2008 (Windsor: University of Windsor, 2010), online: University of Windsor <http://www1.uwindsor.ca/law/sys-tem/files/law40thBook.pdf>. Macdonald's time at Windsor Law was also described, in his own words, on CBC Radio (Ideas), “A Just Life” (14 May 2014), online CBC <http://www.cbc.ca/ideas/episodes/2014/05/14/a-just-life/index.html>.

5 Among other pieces, see MM Kleinhans \& Roderick A Macdonald “What is a Critical Legal Pluralism?” (1997) 12 CJLS 25 at 39. 
Rod.” 6 This is certainly true at Windsor Law where Macdonald's work resonates in the Law School's robust clinical programs, and in its institutional theme of Access to Justice. Indeed, Windsor's first-year Access to Justice (“A2J") course uses as its organising piece one of Rod's articles on different conceptions of A2J. ${ }^{7}$ While the ranks of the professors who worked with Macdonald at Windsor are slowly thinning - and the Winnebago long gone- his institutional and intellectual legacy at this Faculty remain firmly entrenched.

$6 \quad$ La Vie Intellectuelle de Roderick Macdonald at 95.

7 Roderick A Macdonald, “Access to Justice in 2003 - Scope, Scale, Ambitions” in J Bass, WA Bogart \& F Zemans, eds, Access to Justice for a New Century: The Way Forward (Toronto: Law Society of Upper Canada/Irwin Law, 2005). 